\title{
Economic Value Added, Corporation Growth and Overinvestment-Based on State-Owned Corporations
}

\author{
Ying Wang, Yaqi Wang \\ Business School, Beijing Normal University, Beijing, China \\ Email: wangying2014@bnu.edu.cn
}

How to cite this paper: Wang, Y. and Wang, Y.Q. (2016) Economic Value Added, Corporation Growth and OverinvestmentBased on State-Owned Corporations. $\mathrm{Mo}$ dern Economy, 7, 1640-1652.

http://dx.doi.org/10.4236/me.2016.714144

Received: November 4, 2016

Accepted: December 11, 2016

Published: December 14, 2016

Copyright $\odot 2016$ by authors and Scientific Research Publishing Inc. This work is licensed under the Creative Commons Attribution International License (CC BY 4.0).

http://creativecommons.org/licenses/by/4.0/

\begin{abstract}
This paper analyzes if EVA (Economic Value Added) evaluation system can reduce the corporations' overinvestment phenomenon by using the study sample of 204 listed SOEs (state-owned corporations) with the sample period from 2007 to 2012. Then according to Tobin's Q value, we divided all the 204 listed SOEs into two groups, high growth corporations and low growth corporations, and observed if the implementation of EVA has different inhibition effect on the listed SOEs of different growth. The results indicated that EVA can't significantly reduce the listed SOEs' overinvestment, but it has different inhibition effect on different growth corporations. The EVA can significantly reduce low growth listed SOEs' overinvestment, which suggests the EVA evaluation system can improve low growth corporations' investment situation.
\end{abstract}

\section{Keywords}

EVA (Economic Value Added), Corporation Growth, Overinvestment, SOEs

(State-Owned Corporations)

\section{Introduction}

The manager's objectives differ from those of shareholders, resulting in an agency problem. In order to expand the scale of corporation, the managers ignore the interests of shareholders and expand investment for their own interests, resulting in overinvestment phenomenon and the waste of resources. Overinvestment refers to inefficient investment decision-making behavior which accepts investment opportunities that are not optimal for the firm's value, including those with negative net present value, and 
thereby reducing the efficiency of allocating funds. According to 204 listed SOEs' (state-owned corporations) financial reports, we found that the net assets of the listed SOEs increased by nearly $6.2 \%$ in 2008 than in 2007 and increased by $17.7 \%$ in 2009 than in 2008 , after eliminating $5 \%$ of the maximum and minimum values. However, ROE (Rate of Return on Common Stockholders' Equity) decreased by 3.3\% in 2008 than in 2007 and decreased by $4.1 \%$ in 2009 than in 2008. ROE declines in the case of a substantial increase in net assets, which shows that the overinvesting phenomenon is rather serious and SOEs' resources are not fully utilized.

In order to restrain the behavior of corporation managers and change the overinvestment situation, it is necessary to establish an effective performance evaluation system, which can promote the convergence of the fundamental interests of managers and shareholders. On January 1, 2010, the State-owned Assets Supervision and Administration Commission of the State Council (SASAC) promulgated the Interim Measures on the Performance Evaluation of the Heads of SOEs. EVA (Economic Value Added) was declared the assessment indicators in this document.

EVA is an estimate of a firm's economic profit, or the value created in excess of the required return of the company's shareholders. Quite simply, EVA is the net profit less the equity cost of the firm's capital. The idea is that value is created when the return on the firm's economic capital employed exceeds the cost of that capital. EVA was put forward by the consulting firm Stem \& Stewart in the 1980s which intended to present the value created for shareholders accurately. It measures the difference between net profit after tax and capital cost in a certain period of time. It fully considers the calculation of capital costs. To a certain extent, and therefore restrains the abuse of equity capital.

Previous studies have indicated that EVA can alleviate the agency problems and improve investment efficiency. So, we try to clarify that if EVA does have an inhibiting effect on corporations' overinvestment in this paper. In order to understand the relationship between EVA and overinvestment, we distinguish different types of companies with different growth. Growth refers to the ability of sustainable development of enterprises, and means the company's scale gets bigger and market competiveness gets stronger. Growth is an important indicator to measure the future development of enterprises, which was estimated by revenue growth rate in this paper. In addition, we learned that those corporations with lower growth have little development opportunities, if their free cash flow is abundant, the managers will have an overinvestment tendency. Then can the EVA significantly mitigate the lower growth corporations' overinvestment? In order to solve the above questions, we will make research on 204 listed SOEs using the financial report data from 2007 to 2012 to confirm the inhibition effect of the implementation of EVA, and to demonstrate the role of EVA in reducing agency costs and improving the investment situation of SOEs in the market.

In this paper, the overall structure is divided into five parts: the literature review, the hypothesis, the model design and descriptive statistics, the empirical tests and results, the conclusion and analysis. 


\section{Literature Review}

\subsection{Overinvestment}

Overinvestment is defined as corporations allocating free cash flow to negative NPV (Net Present Value) projects. [1] The main causes of overinvestment can be classified in four aspects-agency costs, information asymmetry, bad corporate governance and behavioral finance.

In specific research, Jensen [1] thinks the corporations' managers have a strong motive to establish "corporate empire". They would like to choose negative NPV projects to expand corporation scale due to the separation of ownership and management. Pan Min and Jin Yan [2] find if the information asymmetry is not considered, the particularity of the equity system of Listed Companies in our country will lead to the overinvestment behavior due to equity financing. Wei Minghai and Liu Jianhua [3], Kong Dongmin and Feng Xi [4] support the hypothesis that the low cash dividend policy could promote listed companies' overinvestment. David, and Valeriy Denis [5] believe that financing constraints could affect the corporations' cash holdings, which further affect the level of investment. Zhang Huili and Lu Zhengfei [6] find that in group companies, the higher the proportion of cash held by subsidiaries, the more serious of the overall overinvestment is. Yu Meihong and Xu Longbing and others [7] find that the ownership concentration or the existence of controlling shareholders leads to overinvestment. What's more, the separation of controlling shareholders and cash flow rights further exacerbate the overinvestment level. Tang Xuesong, Zhou Xiaosu and others [8] propose that in our special system, government intervention, political connections and other reasons would lead to overinvestment, as well as Du Xingqiang, CengQuan, et al [9]. In addition, Hua Guiru, Liu Zhiyuan and others [10] find that the investors' emotional change would also lead to overinvestment.

In terms of how to reduce overinvestment, Myers [11] proposes debt financing caused insufficient investment. Jensen [1] supports Myers's conclusion. He points out that the cash dividend and debt could effectively reduce overinvestment. Li Weian and Jiang Tao [12] find that shareholders' behavior governance, board governance, stakeholder governance had positive effect on reducing corporations' overinvestment. However, the effect of the board of supervisors, managers, information disclosure mechanism is not significant. Wei Minghua and Liu Jianhua [3] point out that the low cash dividend policy of state-owned listed companies could lower the overinvestment level, and the company internal governance structure and external governance environment would improve the phenomenon of investment. Wang Yanchao [13] finds that when corporations have excess cash holdings, the corporations with non-constrained financing policy are prone to excessive investment. On the contrary, the financing constraints of the corporation would reduce overinvestment. Yu Meihong, Xu Longbing and others [7] find that compared with private-owned holding company, government-owned holding company overinvestment phenomenon is more serious, and the improvement of external governance environment can inhibit overinvestment in a certain extent. Zhang Huili and Lu Zhengfei [6] find that the improvement of corporate governance 
mechanism could reduce the overall overinvestment level which is caused by the subsidiaries' high cash holding. Kong Dongmin and Feng Xi [4] find that the cash dividends can effectively restrict the overinvestment behavior and play a better inhibitory effect in corporations with a lower free cash flow.

\subsection{EVA Implementation and Overinvestment}

Economic value added is the difference between net profit after tax and capital cost in a certain period of time. It fully takes the opportunity cost of capital into account. And it is a management evaluation system including performance evaluation, incentive compensation and management philosophy. Sun Zheng, Wu Qian [14], Byrne [15], Biddle, Bowen and Wallace [16] point out that EVA is better than NOPAT and FCF to measure the firm's market value and shareholder returns. Bartolomé Deyá Tortella and SandroBrusco [17] find that the managers try to improve the efficiency of investment activities if the corporations use EVA performance evaluation. But it is likely to cause a higher level of debt. Stern [18] points out that the EVA performance evaluation can reduce the operating behavior which couldn't increase the corporation value and shareholder value. And it is significant in both private corporations and state-owned corporations. Worthington and West [19] put forward that EVA can encourage corporation managers to make efforts to increase shareholders' wealth and improve corporation financial performance. Rogerson [20] finds that EVA performance evaluation could push the corporation managers to choose effective investment level so as to improve investment efficiency and enhance the value of corporations. Jan Mouritsen [21] compares the difference between EVA and IC (intellectual capital)'s contributions in increasing corporation value. He finds that on the one hand, EVA is more appropriate to measure the cost of capital, on the other hand, EVA is a results-oriented evaluation method. It constrains the behavior of managers.

Putting EVA into the assessment indicators, the purpose of SASAC is to effectively perform their duties, safeguard the interests of shareholders, preserve and increase the value of state-owned assets, establish effective incentive and restraint mechanisms. Since the EVA performance evaluation began to be implemented form 2010, there is not much domestic research on EVA. This paper summarizes researches about the impact of EVA implementation on overinvestment. Wang Xufang, Wang Li [22] and Liu Jing [23] point out that deducting the cost of capital when we calculate EVA is to guide the managers consider the opportunity cost of capital. The decision principle of project investment is that the expected investment income must be greater than the cost of capital, or the investment value is otherwise damaged. BaoXuedong and Xiao Wenjuan [24] express the same view. They point out that equity capital is a kind of opportunity cost, and investment should be questioned whether the project income can make up for the cost of equity capital. Wang Ligang [25] put forward that the implementation of EVA could make the managers strengthen the feasibility analysis of investment projects to ensure investment income. Yuan Kang [26], Chi Guohua, Wang Zhi, Yang Jin and others [27] think the use of EVA can solve the principal-agent problem and can max- 
imize the interests of shareholders in a certain extent.

In summary, this paper thinks there are many reasons leading to overinvestment. But the most fundamental reason is the agency problem. Due to shareholders and managers have different objectives, the managers expand the scale of corporations and continue to invest to meet their own ambitions. In order to solve the problem, the most effective way is to establish a reasonable performance evaluation system, which can constraint manager's investment behavior. The EVA performance evaluation implemented by SASAC takes the cost of capital into account, which to a certain extent can reduce SOEs' overinvestment phenomenon, especially significant to the low growth corporations. This article conducted an empirical analysis of the implementation of EVA and overinvestment and the research results is expected to provide some support for further research of the EVA performance evaluation system, and to give some references to SASAC and other institutes that are developing or promoting their projects of EVA system for their policy making.

\section{Research Hypothesis}

Investment activity is directly related to a corporation's level of risk and profitability. Reasonable investment will promote the expansion and improve corporation's benefit, but the unreasonable investment will lead to a waste of resources, resulting in the loss of business. Because of the separation of ownership and management, managers often have an "empire" idea. They choose projects with negative net present value and regardless the consequences (Jensen, 1986) [1]. In order to restrict the investment behavior of managers and to improve the efficiency of the investors, it is necessary to establish a reasonable evaluation index system. We can establish performance evaluation indicators to determine the operator's salary, promotion and other vital interests according to the evaluation results, which can directly change the managers' operation behaviors (Holmstrom, 1979) [28].

EVA is an evaluation index proposed by the United States Stewart Stem management consulting firm in 1980s, which can measure corporation value creation ability. It is a kind of corporation performance financial evaluation method based on net operating profit after tax, capital investment and total cost of capital invested. The evaluation index has been widely recognized by scholars. In order to fulfill the responsibilities of state-owned assets of corporations, SASAC promulgated the Interim Measures on the Performance Evaluation of the Heads of SOEs at the end of 2009. EVA was included in the evaluation index. The calculation method: economic value added $=$ operating profit after tax-capital cost $=$ operating profit after tax -adjusted capital cost $^{*}$ average cost of capital rate. This will make the corporation managers start to pay attention to equity capital in theory, so as to adjust the interest relation between owner and operator and improve investment level.

Based on the analysis above, we put forward our first hypothesis.

H1: The implementation of EVA has a significant inhibitory effect on SOEs' overinvestment. 
The general definition of corporation growth is the ability of the corporation to continuously achieve the potential value by mining and using the unused resources. It is a kind of expectation about corporation's future development based on the existing state of corporation development and other internal and external objective factors.(Tang Lingzhi, Zheng Sha, 2011) [29]. The low growth corporations usually have little investment projects and development opportunities. If the cash flow is adequate, the manager will have a strong investment desire, resulting in overinvestment behavior. The implementation of the EVA performance appraisal to SOEs can restrain the unreasonable investment behavior of corporation managers, pushing the managers to consider the interests of shareholders in a certain extent. Then the low growth corporation's investment can be more reasonable. On the contrary, the high growth corporations have more investment and development opportunities. For such corporations, the ultimate goal of managers and shareholders is generally consistent. And the motivation of managers to expand the scale of corporations is in line with the actual situation. So the investment situations of high growth corporations are more reasonable than the low growth. Therefore, the inhibition effect of the implementation of EVA is less significant to high growth corporations than to low growth corporations.

$\mathrm{H} 2$ : The implementation of EVA can significantly reduce the overinvestment of corporations with relatively lower growth.

\section{Model Design and Descriptive Statistics}

\subsection{Model Design}

Our research samples consisted of 204 listed SOEs, covering time period from 2007 to 2012.The list of pilot enterprises was accessible from the official website of SASAC. And CSMAR (China Securities Markets and Accounting Research Database) was our data source for all the financial data used in this paper. We excluded three corporations whose shells were borrowed and one financial corporation, leaving us with 1224 observations. And we choose overinvestment model by Richardson to measure overinvesting behaviors of the listed SOEs, and used the outcome (inv) as the dependent variable to observe the effect of the implementation of EVA evaluation. Then, based on Tobin's Q Value, the samples were divided into two groups with high growth and low growth. OLS regression test was performed on both groups in order to observe different effect of EVA evaluation on corporations' overinvestment with different growth.

\subsubsection{The Estimate of Overinvestment}

Overinvestment refers to the practice of investing into projects with negative NPV. According to the overinvestment model by Richardson [30], we estimated the amount of normal investment behaviors of a corporation, and used the residual returns of the regression as our estimate of inefficient investment behavior. Richardson's model is as follows:

$$
\begin{aligned}
I N V_{t}= & \alpha+\beta_{1} \text { Growth }_{t-1}+\beta_{2} \text { LeV }_{t-1}+\beta_{3} \text { Cash }_{t-1}+\beta_{4} \text { Age }_{t-1}+\beta_{5} \text { Size }_{t-1} \\
& +\beta_{6} \text { Ret }_{t-1}+\beta_{7} I N V_{t-1}+\sum \text { Year }+\sum \text { Industry }+\varepsilon
\end{aligned}
$$


Dependent variable in Equation (1) is normal investment expectation in $t$ years, depending variables Growth $t_{t-1}, \operatorname{LeV}_{t-1}$, Cash $_{t-1}, A_{\text {ge }} e_{t-1}$, Size $_{t-1}, \operatorname{Ret}_{t-1}, I N V_{t-1}$ are the growth(which is estimated by Tobin's Q Value), leverage level, cash holding level, listed years, assets, stock return and investment level. The model also contains dummy variables year and industry to enhance the accuracy of our results. More specific definitions of all variables are as shown in Table 1.

\subsubsection{The Model of the Implementation of EVA and Overinvestment Level}

Our samples were divided into two groups, corporations with high growth and with low growth, according to the Tobin's Q. More specifically, we calculated the average of Tobin's Q of year 2007 to year 2012 for every corporation from our sample. Next, we divided the sample into two groups (one group with high growth and the other group with low growth) by the median of all the averages. The regression was performed independently over both groups to observe the effect of implementing EVA evaluation.

Table 1. Definition of variables.

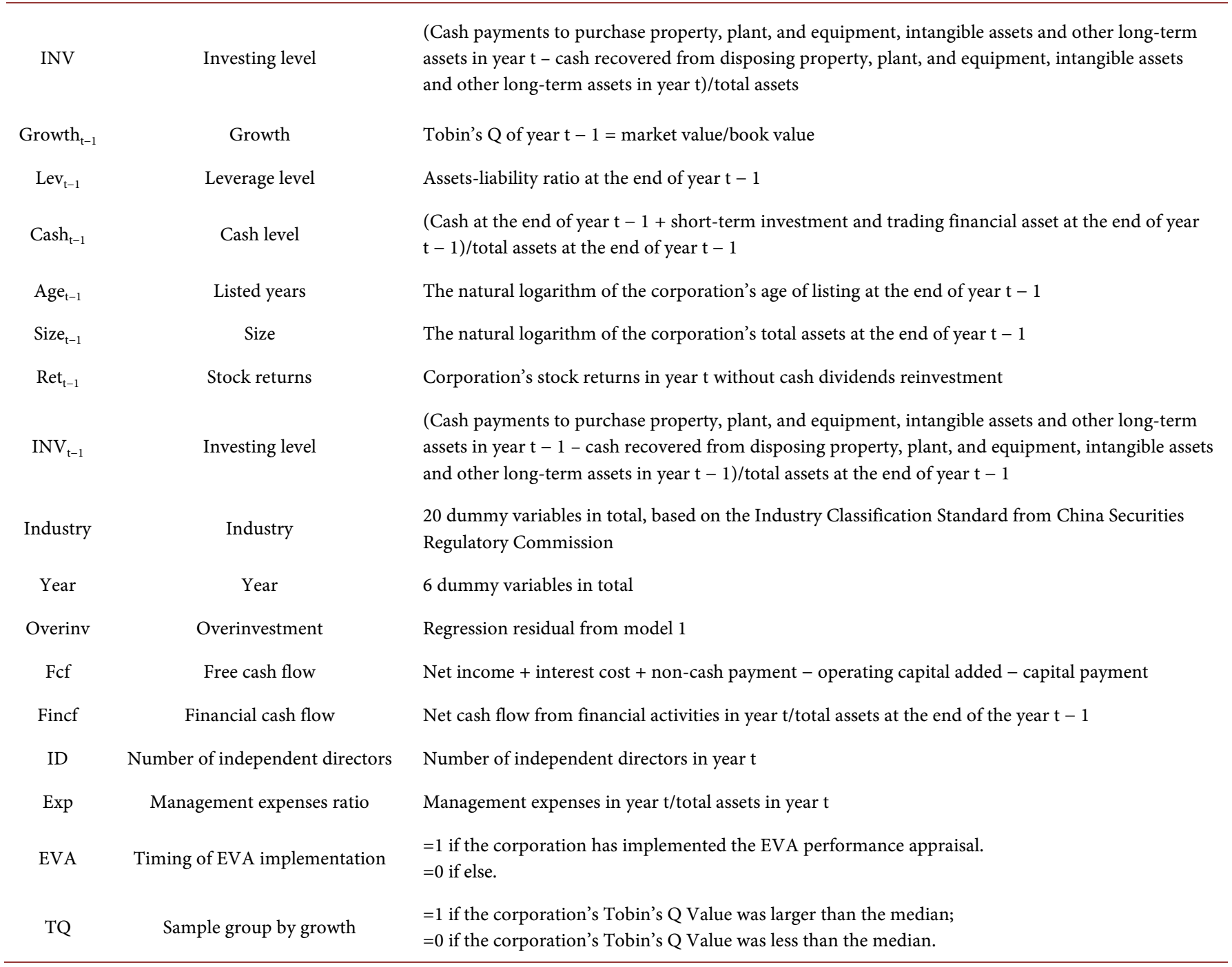


The model we used is as follows:

$$
\begin{aligned}
\text { Overinv }= & \alpha+\beta_{1} \text { EVA }+\beta_{2} \text { Fcf }+\beta_{3} \text { Fincf }+\beta_{4} I D+\beta_{5} \text { Growth }+\beta_{6} \text { Size } \\
& +\beta_{7} \text { Exp }+\sum \text { Year }+\sum \text { Industry }+\varepsilon
\end{aligned}
$$

In the model two, dependent variables are overinvestment (overinv). Learning from the research of Wang Yanchao (2009) [13], Zhang Huili and Lu Zhengfei (2012) [6], Fang Hongxing and Jin Yuna (2013) [31], Zhang Xianzhi, Li Qi et al. (2013) [32] [33], et al, we choose free cash flow $(F c f)$, financing cash flow $(F i n c f)$, the number of independent directors (ID), assets (Size), growth (Growth) and management expense ratio $\left(E_{x p}\right)$ as our independent variables. We also used a dummy variable EVA, which reflect whether the company has implemented EVA evaluation. This variable allowed us to observe the difference of the SOEs' overinvestment behaviors before and after implementing EVA evaluation. Year variable was also controlled in model two, as well as industry variable, to enhance the accuracy of our regression results.

\subsection{Descriptive Statistics}

Descriptive statistics for the main variables are as follows. We used the econometric software STATA to conduct all the descriptive statistics and empirical tests in this paper. Overinvestment of all the corporations in our sample ranged from a minimum of -0.5373 to a maximum of 0.4601 , with an average of 0 , which indicated that there are underinvestment among SOEs as well as overinvestment. Size had an average of 22.5377, a minimum value of 2 and a maximum value of 6 in our sample. Descriptive statistics of other variables are as shown in Table 2, so we don't repeat the results here. We calculated the average of Tobin's Q from year 2007 to 2012 for each corporation, after deleting two corporations with missing data. All the corporations were divided into two groups by the median of the average 1.9350, one with high growth and the other with low growth.

Table 3 shows the descriptive statistics of overinvestment among the whole sample and two different growth groups. The overinvestment of SOEs with low growth is bigger than corporations with high growth in 2007 and 2008, while lower than corporations with high growth afterwards, as reflected by the median number. According to Pilot List of SOEs to Implement EVA in 2007-2009 by SASAC, there were 80 pilot participants among in 2007, 89 pilot participants in 2008, and 122 pilot participants in 2009. With the SOEs starting to implement EVA evaluation system one after another, the overinvestment of corporations with low growth began to reduce, and finally became less than the overinvestment of corporations with high growth, which correspond to our hypothesis two in some extent.

Table 4 showed the change in overinvestment of the corporations from the whole sample, high growth group and low growth group after implementing EVA. We found an obvious positive correlation between overinvestment and the implementation of EVA, while the median was less after the implementation of EVA in the low growth group, which is matched with our hypothesis two. Besides, we found that the overin- 
vestment level in corporations with low growth is higher than the whole sample and high growth group, yet reduced after implementing EVA and became nearer to the whole sample and high growth group, which supports our hypothesis two as well.

\section{Empirical Test and Results}

\subsection{The Implementation of EVA Evaluation and SOEs' Overinvestment}

Table 5 is the regression results of our model two, which can be observed the effect of implementing EVA to SOEs' overinvestment. The results showed the correlation between implementing EVA and overinvestment is positive, but this conclusion didn't pass the significance test. We run White test afterwards, which proved there was no heteroscedasticity. So our hypothesis one was not supported based on our sample data,

Table 2. Descriptive statistics of main variables.

\begin{tabular}{cccccc}
\hline Variable & Average & Median & Standard deviation & Minimum value & Maximum value \\
\hline Overinv & 0.0000 & -0.0070 & 0.0492 & -0.5373 & 0.4601 \\
Fcf & 0.0033 & 0.0001 & 0.0209 & -0.0421 & 0.3157 \\
Fincf & 0.0508 & 0.0083 & 0.1811 & -2.7530 & 1.4845 \\
ID & 3.5030 & 3 & 0.7704 & 2 & 6 \\
Size & 22.5377 & 22.2610 & 1.7291 & 18.1812 & 28.4052 \\
Growth & 2.2182 & 1.6849 & 1.6648 & 0.5893 & 15.9682 \\
Exp & 0.0452 & 0.0397 & 0.0361 & 0.0007 & 0.7344 \\
\hline
\end{tabular}

Table 3. Descriptive statistics of overinvestment (overinv).

\begin{tabular}{ccccccc}
\hline \multirow{2}{*}{ Year } & \multicolumn{5}{c}{ 204 SOEs } \\
\cline { 2 - 6 } & \multicolumn{2}{c}{ whole sample } & \multicolumn{2}{c}{ high growth } & \multicolumn{2}{c}{ low growth } \\
\cline { 2 - 6 } & average & median & average & median & average & median \\
\hline 2007 & $1.53 \mathrm{e}-09$ & -0.0103 & -0.0105 & -0.0146 & 0.0113 & -0.0056 \\
2008 & $-2.95 \mathrm{e}-09$ & -0.0041 & -0.0032 & -0.0062 & 0.0033 & -0.0038 \\
2009 & $2.06 \mathrm{e}-09$ & -0.0097 & 0.0019 & -0.0097 & -0.0019 & -0.0098 \\
2010 & $-2.55 \mathrm{e}-09$ & -0.0089 & -0.0054 & -0.0073 & 0.0054 & -0.0094 \\
2011 & $9.85 \mathrm{e}-10$ & -0.0060 & 0.0017 & -0.0018 & -0.0018 & -0.0116 \\
2012 & $-5.29 \mathrm{e}-10$ & -0.0037 & -0.0092 & 0.0012 & 0.0091 & -0.0122 \\
\hline
\end{tabular}

Table 4. Descriptive statistics of overinvestment (overinv).

\begin{tabular}{ccccc}
\hline & \multicolumn{2}{c}{ before implementing EVA } & \multicolumn{2}{c}{ after implementing EVA } \\
\hline & average & median & average & median \\
\hline whole sample & -0.0022 & -0.0085 & 0.0008 & -0.0068 \\
high growth & -0.0048 & -0.0093 & 0.0003 & -0.0050 \\
low growth & 0.0003 & -0.0064 & 0.0012 & -0.0084 \\
\hline
\end{tabular}


Table 5. The implementation of EVA and SOEs' overinvestment.

\begin{tabular}{|c|c|c|c|c|}
\hline variable & Coef. & Std. Err. & $\mathrm{t}$ & $P>|t|$ \\
\hline Fcf & 0.1513 & 0.0844 & 1.79 & 0.073 \\
\hline Fincf & 0.0774 & 0.0085 & 9.15 & 0.000 \\
\hline ID & -0.0029 & 0.0022 & -1.36 & 0.174 \\
\hline Size & -0.0001 & 0.0013 & -0.09 & 0.932 \\
\hline Growth & 0.0005 & 0.0011 & 0.48 & 0.633 \\
\hline Exp & -0.0223 & 0.0450 & -0.50 & 0.620 \\
\hline EVA & 0.0044 & 0.0042 & 1.05 & 0.294 \\
\hline \multicolumn{2}{|c|}{ Obs } & & 1092 & \\
\hline \multicolumn{2}{|c|}{$\mathrm{F}$} & & 4.52 & \\
\hline \multicolumn{2}{|c|}{$\mathrm{R}^{2}$} & & 0.0887 & \\
\hline \multicolumn{2}{|c|}{ Adjusted $\mathrm{R}^{2}$} & & 0.0691 & \\
\hline
\end{tabular}

Table 6. EVA evaluation, corporation growth and overinvestment.

\begin{tabular}{|c|c|c|c|}
\hline \multirow{2}{*}{ Independent variables } & \multicolumn{3}{|c|}{ Samples } \\
\hline & the whole sample & high growth & low growth \\
\hline EVA & $\begin{array}{l}0.00443 \\
(0.0042)\end{array}$ & $\begin{array}{c}0.0002 \\
(0.0055)\end{array}$ & $\begin{array}{l}0.0117^{\star *} \\
(0.0058)\end{array}$ \\
\hline Fcf & $\begin{array}{c}0.1513 \\
(0.0844)\end{array}$ & $\begin{array}{c}0.0484 \\
(0.0967)\end{array}$ & $\begin{array}{c}0.4799^{* * *} \\
(0.1670)\end{array}$ \\
\hline Fincf & $\begin{array}{c}0.0774^{\star * *} \\
(0.0085)\end{array}$ & $\begin{array}{l}-0.0005 \\
(0.0099)\end{array}$ & $\begin{array}{c}0.2066^{* * *} \\
(0.0134)\end{array}$ \\
\hline ID & $\begin{array}{l}-0.0029 \\
(0.0022)\end{array}$ & $\begin{array}{l}-0.0000 \\
(0.0030)\end{array}$ & $\begin{array}{l}-0.0015 \\
(0.0028)\end{array}$ \\
\hline Size & $\begin{array}{l}-0.0001 \\
(0.0013)\end{array}$ & $\begin{array}{c}0.0009 \\
(0.0021)\end{array}$ & $\begin{array}{l}-0.0028 \\
(0.0018)\end{array}$ \\
\hline Growth & $\begin{array}{c}0.0005 \\
(0.0011)\end{array}$ & $\begin{array}{c}0.0012 \\
(0.0012)\end{array}$ & $\begin{array}{c}0.0012 \\
(0.0055)\end{array}$ \\
\hline Exp & $\begin{array}{l}-0.0223 \\
(0.0450)\end{array}$ & $\begin{array}{c}0.0000 \\
(0.0536)\end{array}$ & $\begin{array}{l}-0.0510 \\
(0.0717)\end{array}$ \\
\hline Year & control & control & control \\
\hline Obs & 1092 & 567 & 525 \\
\hline $\mathrm{R}^{2}$ & 0.0887 & 0.0445 & 0.3605 \\
\hline
\end{tabular}

Dependent variable in this model is overinvestment (overinv), as defined in Table 1; The above numbers in each cell are estimated coefficient, the number below in braces are $t$ values; ${ }^{*},{ }^{* *},{ }^{* *}$ means $10 \%, 5 \%$ and $1 \%$ significance level.

which means the implementation of EVA evaluation may not have depressing effect on SOEs' overinvestment as we expected.

\subsection{The Implementation of EVA, Corporation Growth and Overinvestment}

Table 6 shows the regression results of model two, by which we observed the different 
Table 7. The implementation of EVA and over-investment.

\begin{tabular}{ccccc}
\hline Variable & Coef. & Std. Err. & $\mathrm{t}$ & $\mathrm{P}>|\mathrm{t}|$ \\
\hline Fcf & 0.0063 & 0.0940 & 0.07 & 0.947 \\
ID & 0.0959 & 0.0114 & 8.43 & 0.000 \\
Size & -0.0043 & 0.0035 & -1.22 & 0.224 \\
Growth & -0.0018 & 0.0022 & -0.83 & 0.407 \\
Exp & 0.0020 & 0.0021 & 0.95 & 0.343 \\
EVA & -0.1191 & -0.1191 & -1.95 & 0.052 \\
& & & 373 & \\
& Obs & & 4.95 & \\
& F & & 0.2287 & \\
& Adjusted & & 0.1825 \\
\end{tabular}

effect of implementing EVA to the overinvestment of corporations with different growth. The depressing effect of implementing EVA on low growth corporations was statistically significant, and the significance level became higher with cluster sampling. As for the sample group with a higher growth, the effect was not proved statistically significant. Our empirical results supported our hypothesis two, which means that implementing EVA does have a significant negative effect on overinvesting of SOEs with relatively low growth. So applying EVA evaluation can improve low growth SOEs' overinvestment.

\subsection{Robust Test}

We selected new sample of overinvestment for a robust test. About $2 / 3$ of our estimated overinvestment were negative, which means these corporations didn't overinvest. In order to ensure the stability and reliability of our rejection to hypothesis one, we ranked the whole sample according to the order from small to large and select the largest $1 / 3$ of them all to run a new regression for our hypothesis one. The empirical results were as showed in Table 7, indicating that implementing EVA has no statistically significant effect to overinvestment, which is consistent with our former test. So hypothesis one was not accepted.

\section{Conclusions and Analysis}

Through the regression and robust test above, we could reach the conclusion that implementing EVA has no significant depressing effect to SOEs' overinvestment, while implementing EVA does have a significant depressing effect to the corporation with a relatively low growth.

Based on the previous paper, we thought that low growth corporation is usually related to relatively smaller development space and less growth-type investment project. These corporations are more likely to go beyond the proper investment level with corporations' cash flow, if the managers were to establish their business empire or simply achieve success in maximizing shareholder's wealth. EVA is a more thorough assess- 
ment system which takes capital cost into consideration and emphasizes the enterprise surplus value. So EVA assessment system can encourage managers to fully consider the capital cost and investment income, thus reducing overinvestment and maintaining a more effective investment level. As for those who has a higher growth ratio, we expect them to be more well-developed, and with more growth opportunities and earning projects. Managers' investment decision can be more reasonable when they put investment into these available growth-type opportunities. Therefore, overinvestment in these corporations may not be so serious. Implementing EVA assessment had no significant effect to corporations' overinvestment with high growth, but had significant depressing effect on corporations with low growth. In conclusion, we have reasons to believe that SASAC requiring EVA assessment on SOEs does help mitigating agency cost, reducing overinvestment, and especially improving corporations' investment situation with low growth.

\section{References}

[1] Jensen, M.C. (1986) Agency Costs of Free Cash Flow, Corporate Finance, and Takeovers. The American Economic Review, 323-329.

[2] Pan, M. and Jin, Y. (2003) Asymmetric Information, Equity System Arrangement and Listed Companies' Overinvestment. Financial Research, 1, 36-45.

[3] Wei, M.H. and Liu, J.H. (2007) State-Owned Companies' Dividends, Governance Factors and Overinvestment. Management World, 4, 88-95.

[4] Kong, D.M. and Feng, X. (2012) A Study of Dividends Policy and Over-Investment of Company. Investment Research, 6, 29-44.

[5] Denis, D.J. and Sibilkov, V. (2010) Financial Constraints, Investment, and the Value of Cash Holdings. Review of Financial Studies, 23, 247-269.

https://doi.org/10.1093/rfs/hhp031

[6] Zhang, H.L. and Lu, Z.F. (2012) Cash Distribution, Corporate Governance and Overinvestment-An Empirical Study on the Cash Holdings of Chinese Listed Companies and Their Subsidiaries. Management World, 3, 141-149.

[7] Yu, H.H. and Xu, L.B. (2010) Ultimate Controlling Shareholders' Control and Over-Investment of Free Cash Flow. Economic Research, 8, 103-114.

[8] Tang, X.S., Zhou, X.S. and Ma, R.J. (2010) Government Interference, GDP Growth and State-Owned Companies' Over-Investment. Financial Research, 8, 33-84.

[9] Du, X.Q., Zeng, Q. and Du, Y.J. (2011) Political Connection, Over-Investment and Corporate Value: Empirical Evidence from State-Owned Listed Companies. Financial Research, 8, 93-110.

[10] Hua, G.R., Liu, Z.Y. and Xu, Q. (2010) Investor Sentiment, Corporate Investment Behavior and Resource Allocation Efficiency. Accounting Research, 11, 49-55.

[11] Myers, S.C. (1977) Determinants of Corporate Borrowing. Journal of Financial Economics, 5, 147-175. https://doi.org/10.1016/0304-405X(77)90015-0

[12] Li, W.A. and Jiang, T. (2007) A Study on Corporate Governance and the Over-Investment Behavior of Enterprises: Evidence from Chinese Listed Companies. Economics of Financial and Trade, 12, 56-61.

[13] Wang, Y.C. (2009) Financing Constraints, Cash Holdings and Over-Investment. Financial 
Research, 7, 121-133.

[14] Sun, Z. and Wu, Q. (2003) Economic Value Added: Thinking under Reputation. Accounting Research, 3, 8-14.

[15] O’Byrne, S.F. (1997) EVA and Shareholder Return. Financial Practice and Education, 7, 50-54.

[16] Biddle, G.C., Bowen, R.M. and Wallace, J.S. (1997) Does EVA Beat Earnings? Evidence on Associations with Stock Returns and Firm Values. Journal of Accounting and Economics, 24, 301-336. https://doi.org/10.1016/0304-405X(77)90015-0

[17] Tortella, B.D. and Brusco, S. (2003) The Economic Value Added (EVA): An Analysis of Market Reaction. Advances in Accounting, 20, 265-290. https://doi.org/10.1016/s0882-6110(03)20012-2

[18] Stern, J. (2004) Corporate Governance, EVA, and Shareholder Value. Journal of Applied Corporate Finance, 16, 91-99. https://doi.org/10.1111/j.1745-6622.2004.tb00541.x

[19] Worthington, A.C. and West, T. (2001) Economic Value-Added: A Review of the Theoretical and Empirical Literature. Asian Review of Accounting, 9, 67-86. https://doi.org/10.1108/eb060736

[20] Rogerson, W.P. (1997) Intertemporal Cost Allocation and Managerial Investment Incentives: A Theory Explaining the Use of Economic Value Added as a Performance Measure. Journal of Political Economy, 105, 770-795. https://doi.org/10.1086/262093

[21] Mouritsen, J. (1998) Driving Growth: Economic Value Added versus Intellectual Capital. Management Accounting Research, 9, 461-482. https://doi.org/10.1006/mare.1998.0090

[22] Wang, X.F. and Wang, L. (2012) The Chinese Characteristics of EVA Assessment. Finance and Accounting Monthly, 23, 59-60.

[23] Liu, J. (2011) Thoughts on Introducing the Economic Value Added of the Central Enterprises to Checking the Management Achievements. Finance and Accounting Monthly, 14, 13-14.

[24] Bao, X.D. and Xiao, W.J. (2012) The Application of Economic Value Added in Management. Chinese Commerce and Trade, 9, 83-83.

[25] Wang, L.G. (2013) Enlightenment from the Economic Value Added of Central Enterprises. Business Accounting, 3, 87-88.

[26] Yuan, G. (2012) Brief Discussion on Economic Value Added Evaluation Method. Research of Finance and Accounting, 11, 62-64.

[27] Chi, G.H., Wang, Z. and Yang, J. (2013) Does EVA Valuation Enhance Enterprise Value: Empirical Evidence from State-Owned Listed Companies in China. Accounting Research, $11,60-66$.

[28] Hölmstrom, B. (1979) Moral Hazard and Observability. The Bell Journal of Economics, 10, 74-91. https://doi.org/10.2307/3003320

[29] Tang, L.Z. and Zheng, S. (2011) A Comprehensive Study on the Growth of Enterprises. Managers, 7, 8-9.

[30] Richardson, S. (2006) Over-Investment of Free Cash Flow. Review of Accounting Studies, 11, 159-189. https://doi.org/10.1007/s11142-006-9012-1

[31] Fang, H.X. and Jin, Y.N. (2013) Corporate Governance, Internal Control and Inefficient Investment: Theoretical Analysis and Empirical Evidence. Accounting Research, 7, 63-69.

[32] Zhang, X.Z. and Li, Q. (2012) An Empirical Analysis of Impacts of EVA-Based Performance Evaluation on Over-Investment Behavior of Central SOEs. Contemporary Finance \& Economics, 5, 119-128.

[33] Liu, F.W. and Li, Q. (2013) Market Competition, EVA Evaluation and Corporate Over-Investment. Accounting Research, 2, 54-62. 
Submit or recommend next manuscript to SCIRP and we will provide best service for you:

Accepting pre-submission inquiries through Email, Facebook, LinkedIn, Twitter, etc. A wide selection of journals (inclusive of 9 subjects, more than 200 journals)

Providing 24-hour high-quality service

User-friendly online submission system

Fair and swift peer-review system

Efficient typesetting and proofreading procedure

Display of the result of downloads and visits, as well as the number of cited articles

Maximum dissemination of your research work

Submit your manuscript at: http://papersubmission.scirp.org/

Or contact me@scirp.org 